\title{
Spring Freeze Damage of Pecan Bloom: A Review
}

\author{
Amandeep Kaur ${ }^{1}$, , Louise Ferguson ${ }^{2}$, Niels Maness ${ }^{1}$, Becky Carroll ${ }^{1}$, William Reid ${ }^{3}$ \\ and Lu Zhang ${ }^{1, *}$ \\ 1 Department of Horticulture and Landscape Architecture, Oklahoma State University, \\ Stillwater, OK 74078, USA; amandeep.kaur@okstate.edu (A.K.); niels.maness@okstate.edu (N.M.); \\ becky.carroll@okstate.edu (B.C.) \\ 2 Department of Plant Sciences, University of California Davis, One Shields Avenue, Davis, CA 95616, USA; \\ lferguson@ucdavis.edu \\ 3 Department of Horticulture and Natural Resources, Kansas State University, Manhattan, KS 66506, USA; \\ wreid@ckt.net \\ * Correspondence: luzhang@okstate.edu; Tel.: +1-405-744-6463
}

Received: 30 September 2020; Accepted: 23 October 2020; Published: 13 November 2020

\begin{abstract}
Pecan is native to the United States. The US is the world's largest pecan producer with an average yearly production of 250 to 300 million pounds; 80 percent of the world's supply. Georgia, New Mexico, Texas, Arizona, Oklahoma, California, Louisiana, and Florida are the major US pecan producing states. Pecan trees frequently suffer from spring freeze at bud break and bloom as the buds are quite sensitive to freeze damage. This leads to poor flower and nut production. This review focuses on the impact of spring freeze during bud differentiation and flower development. Spring freeze kills the primary terminal buds, the pecan tree has a second chance for growth and flowering through secondary buds. Unfortunately, secondary buds have less bloom potential than primary buds and nut yield is reduced. Spring freeze damage depends on severity of the freeze, bud growth stage, cultivar type and tree age, tree height and tree vigor. This review discusses the impact of temperature on structure and function of male and female reproductive organs. It also summarizes carbohydrate relations as another factor that may play an important role in spring growth and transition of primary and secondary buds to flowers.
\end{abstract}

Keywords: pecan; spring freeze; bud formation; flowering; carbohydrates; temperature

\section{Introduction}

Pecan (Carya illinoinensis (Wangenh.) K. Koch) is a member of the Juglandaceae family which has North American, Anatolian, and black walnut species. The fruits/nuts are highly nutritional, rich in fats, carbohydrates, proteins, Calcium (Ca), Phosphorus (P), Magnesium $(\mathrm{Mg})$ and vitamins A, B, and E [1]. Pecans are woody perennial with a relatively long juvenile growth phase. It takes from 4 to 12 years to produce the first nut crop depending on pecan cultivar and cultural practice [2]. Pecan is deciduous with mixed reproductive buds. Bud maturation is non-uniform [3]. Pecan trees are monoecious (produces male (staminate) and female (pistillate) inflorescences on different parts of the same tree). Pistillate flowers develop from the terminal bud of the current seasons shoot while the male inflorescence is produced by primary compound buds of previous season branches [4]. In pecan, the current season's growth occurs on only the distal tip of last year's terminal growth. The buds on the basal half of the limb remain dormant [5]. The staminate flowers are called catkins and are arranged in groups of 2 to 8 by a common peduncle. The pistillate flower is a star-shaped terminal raceme [2]. Pecan produces a large number of male to female flowers per branch. There are up to 115 male flowers per stalk. There are 2 catkins per bud, 3 stalks per catkin, $110-115$ flowers per stalk, 
3-4 anthers per flower, approximately 2000 pollen grains per anther. The number of female flowers varies (may be 3-5 flowers per terminal) depending on cultivars and shoot vigor [6].

Pecan has two types of dichogamy. Protandry or type I (exhibited by 'Pawnee', 'Peruque', 'Giles', 'Oconee', 'Caddo', and 'Desirable') are protandrous cultivars producing anthers and pollen on the male flowers before stigmas of the female flowers are receptive. Protogyny or type II (exhibited by 'Kanza', 'Maramec', 'Kiowa', 'Lakota', and 'Colby') are protogynous cultivars producing anthers and pollen on the male flowers after the stigmas of the female flowers are receptive [1,2,7]. For successful wind-borne cross-pollination, trees of the opposite dichogamous type should be within 150 feet of one another. In northern climates bloom time varies among the cultivars [8]. The variability in pistillate flowering due to heterodichogamy does not harm the tree but can adversely affect nutmeat production and quality if pollen is not abundantly available when female flowers are receptive $[9,10]$.

Pecan bloom may be interrupted by spring freeze. Damaging spring freeze occurs approximately every 3 out of 5 years in Oklahoma [11]. This frequency suggests that freeze damage can be a major problem for early blooming cultivars susceptible to cold injury. In addition to spring frost frequency, timing of spring frost may also be an important factor in spring frost damage [12]. An early April 2007 freeze in the southeastern US severely damaged trees during bud breaking and bloom [13]. This freeze, "the worst ever seen" [13] caused an estimated \$117.7 million in losses in North Carolina, Tennessee and Georgia. Another April 2018 freeze in Oklahoma damaged 70 percent of the pecan crop (estimate from pecan grower's meetings). While the predominant focus of global warming research has focused on the effects of increasing temperatures and droughts, climatic change may also increase the risk of spring frost damage in temperate regions [14,15]. Therefore, studying spring freeze and its related aspects is important and this review we will focus on the impact of spring freeze on pecan trees especially on buds and flowering. Furthermore, this review will discuss the effect of temperature on male and female flower organs and carbohydrates in relation to flowering.

\section{Effect of Freeze on Pecan}

\subsection{Types of Freeze Injuries in Pecan}

Freeze injury to pecan trees can occur in the autumn before they have cold-acclimated $[16,17]$, during winter dormancy [18], or in the spring [19] during and after bud differentiation processes have initiated. The damage due to low temperature $-10{ }^{\circ} \mathrm{C}$ and $-2{ }^{\circ} \mathrm{C}$ in autumn $[20,21],-12{ }^{\circ} \mathrm{C}$ and $-3{ }^{\circ} \mathrm{C}$ in winter [14,16,19], and $-15^{\circ} \mathrm{C}$ in later winter [18], $-5^{\circ} \mathrm{C}$ in spring [20] has been observed to different tree parts. The autumn injury occurs before trees harden off and in some cases the trees may be fully foliated. This freeze injury is generally caused by non-freezing daytime temperatures followed by rapid below freezing for night temperature [17]. Autumn freeze can cause a premature defoliation and canopy, branch, and root death which only becomes visible after spring bud break [21]. The typical symptoms of winter injury are death and browning of the cambium, inner bark and phloem, as well as splitting and browning of the rootstock inner bark and phloem, delayed bud break [20,22]. The fall freeze injury can precipitate early bud break increasing bud and flower susceptibility to spring freeze injury [17]. Sparks and Payne [23] suggested late spring freezes were the most harmful to pecan production as it is becoming more frequent in recent years and causes damage to buds and flowers.

\subsection{Spring Freeze and the Factors Influencing Severity of Freeze Damage in Pecan}

Dormancy is defined as a state of reduced or paused physiological processes and growth. A fully dormant bud is maximally resistant to freezing temperatures [24]. Endodormancy or winter-dormancy is true dormancy in that bud growth is inhibited by the physiological condition of tree and is protected low temperatures. Once conditions to break endodormancy commence the tree enters ecodormancy; imposed dormancy, a quiescent period when growth is prevented by external environmental conditions. Ecodormancy release and spring bud growth is regulated by external factors, primarily temperature [25]. The onset of bud swelling indicates that the transition from endodormancy to ecodormancy has 
occurred. At this stage, the bud water content increases and the buds become increasingly susceptible to freezing [26]. The cambium is also very sensitive to freezing temperature at this stage [23]. Spring bud development is critical for yield as pecan produces its primary flush of flowers once a year; freeze damage during bud-break and bloom decreases yield. During a warm spring, bud-break occurs earlier. During a cool spring, bud-break will be delayed. However, once it does start to warm up, bud-break should occur rapidly and early [27]. Spring low temperature injury is generally confined to newly developing shoots and is followed by regrowth from secondary and tertiary buds. This can lead to a significant decrease in crop production as secondary and tertiary buds have lower crop potential than primary buds [17].

\subsubsection{Secondary Buds}

Pecan trees have two types of buds, mixed and compound. Terminal buds are mixed buds and potentially contain both reproductive, female flowers and vegetative tissue, shoot and leaves. If the terminal mixed bud aborts during winter, a lateral bud predominates as the distal, most terminal bud. In pecan, most of the buds are compound buds with multiple buds within the compound bud. Generally, there are three compound buds at each node, primary (biggest one), secondary (smaller), and tertiary buds (smallest) (Figure 1a). The compound bud contains two catkin buds (male flowers) and a central mixed bud [28]. If the primary buds are injured or killed by frost, the secondary buds produce new shoot growth with both staminate and pistillate inflorescences. However, the percentage of normal flowering is less than that of the primary buds $[28,29]$. After freeze on 13 April $\left(-5.5{ }^{\circ} \mathrm{C}\right)$, primary buds produced $38 \%$ catkins and $1.8 \%$ pistillate flowers, while secondary buds produced only $16 \%$ catkins and $2.6 \%$ pistillate flowers [19]. The following discussion summarizes the studies of secondary bud growth after the primary buds were killed by frost.

The production of pistillate flowers from secondary buds after a late spring freeze has been previously reported. Sparks [30] examined the hypothesis that unseasonal low temperatures near during bud break causes abnormal flowering. During normal flowering, the pistillate flowers develop from terminal apex, while in abnormal flowering staminate flowers develop from the terminal apex of pistillate inflorescences [30-32] (1.c). The extent of abnormal flowering can vary from few staminate flowers to pistillate inflorescence apex along with pistillate flowers to completely replacing pistillate by staminate flowers [30-32]. 'Desirable' was especially sensitive to the environmental changes that cause formation of abnormal flowers [30]. They suggested spring freezes, not genetic instability induced the atypical flowering [30]. Late spring freezes in Alabama and Georgia produced the same results; secondary buds that developed after late spring freeze produced abnormal flowers [33,34]. Similarly, pistillate flowers developed from secondary buds in 'Desirable' pecan trees after a late spring freeze [35]. However, around 50 days after flowering (DAF) production of fruiting terminals and cluster size was reduced by $27 \%$ and $60 \%$, respectively and most of the flowers were abnormal. This suggests that the flower drop associated with the reduction of pistillate flowers on freeze-damaged 'Desirable' trees was due to damaged flowers rather than incompetent pollination and fertilization [35]. The epicormics shoot growth from lateral buds after loss of apical dominance due to a severe freeze $\left(-5^{\circ} \mathrm{C}\right)$ was also observed in Oak Ridge, Tennessee [13]. Similarly, the new shoot growth from secondary buds was observed after damage or death of terminal primary buds by a freeze on 14 April 1980 and 18 April 2020 [36,37] (Figure 1b).

Some cultivars are more likely than others to exhibit abnormal flowers in response to a spring freeze. For example, there was no formation of abnormal pistillate flowers from secondary buds on 'Kiowa', while the secondary buds of freeze-damaged 'Desirable' trees produced shorter shoots with higher flower and fruit drop [35].

The key factors for inducing abnormal flowering are the critical temperatures between $-1.7^{\circ} \mathrm{C}$ to $-2.2^{\circ} \mathrm{C}$ along with pistillate flower bud development within 8 to 10 days before bud break. The effect that temperatures during the days preceding critical temperatures may have an effect on abnormal flowering and in order to determine this the normal minimum and maximum temperatures for the 
10 days preceding a freeze were compared: the 23rd, 27th, and 29th of March (1955) and 1988 were compared [30]. The first freeze was on the $23 \mathrm{rd}$ of March with a minimum temperature of $-2.2^{\circ} \mathrm{C}$ making 23 March the reference date. The maximum temperature was constant and high, averaging $23.6^{\circ} \mathrm{C}$ in 1955 and 1988 for the seven days prior to the freeze event on the 23 March. A sudden drop in the minimum temperature from a relatively high $15.9{ }^{\circ} \mathrm{C}$ in 1955 and $8.4{ }^{\circ} \mathrm{C}$ in 1988 to below freezing at approximately $-2{ }^{\circ} \mathrm{C}$ in 1955 and $-1{ }^{\circ} \mathrm{C}$ in 1988 was observed. From the above observations, Sparks [30] hypothesized that the high temperature patterns preceding the freeze events may be related to the presence of abnormal flowering after the freeze event. Similar trend of sudden temperature drop from high to lower: examples are $17{ }^{\circ} \mathrm{C}$ to $-5{ }^{\circ} \mathrm{C}, 24{ }^{\circ} \mathrm{C}$ to $-16{ }^{\circ} \mathrm{C}, 32{ }^{\circ} \mathrm{C}$ to $-20{ }^{\circ} \mathrm{C}$, sudden $-12{ }^{\circ} \mathrm{C}$ (without any prior freeze temperature), $15^{\circ} \mathrm{C}$ to $-5^{\circ} \mathrm{C}$ observed by wood [20], Wood [18], Smith [16], Smith [21], Gu et al. [13].

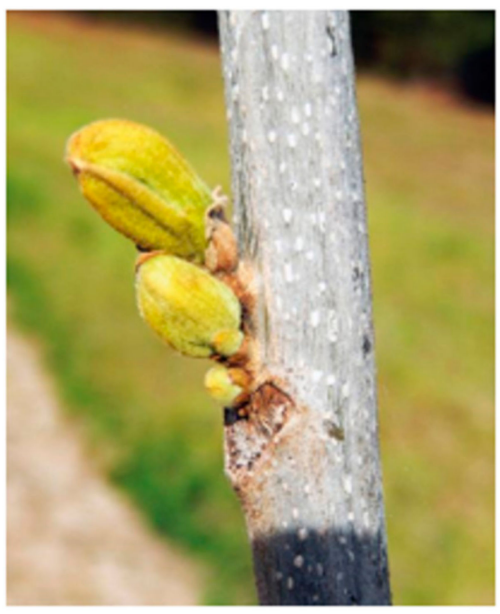

(a)

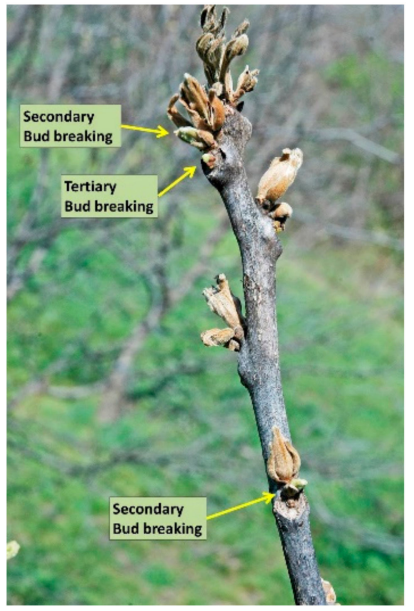

(b)

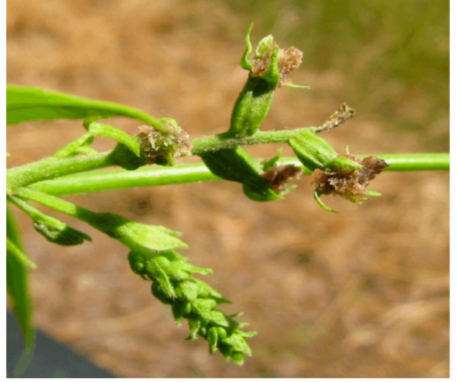

(c)

Figure 1. (a) Multiple buds at a node [38]. (b) Dead terminal buds after 15 April 2014 freeze in 'Jayhawk' —emerging secondary and tertiary buds. Past studies reported only $15 \%$ of these emerging secondary buds will produce pistillate flowers after new shoot growth [39]. (c) Abnormal flowering of 'Desirable' pecan on secondary growth, following a late spring freeze [40].

\subsubsection{Bud Growth Stages}

Buds grow in stages; outer bud scale intact (dormant), outer bud scale split, outer bud scale shed (bud swell), inner scale shed, leaf burst, and leaf expansion [41]. When the pecan bud breaks dormancy, and enlarges during spring it is most susceptible to environmental changes; specifically, freezing temperatures before their major morphological transition to flowers [20,30]. Freezes produce little injury to dormant or swollen buds but cause severe bud damage at the leaf expansion stage $[14,30,41]$. A sudden drop in temperature from $17^{\circ} \mathrm{C}$ to $-5^{\circ} \mathrm{C}$ for three consecutive nights with daily highs being $\approx 8$ to $9^{\circ} \mathrm{C}$ on 13 March 1997-1998 caused a distinct pattern of bud death and reduced shoot and leaf growth from the bottom to the top of the canopy. The buds at the bottom were at an advanced stage, swelling and breaking) and incurred more damage than upper canopy buds [20]. Smith and Cheary [42] reported similar results including that 'Pawnee', a cultivar resistant to winter cold had severe spring freeze damage during advanced bud development. While $-4{ }^{\circ} \mathrm{C}$ is not harmful for dormant buds, temperatures below $-2.22^{\circ} \mathrm{C}$ may cause freeze damage in green buds [37]. For example, even after the 16 April 2018 freeze with a temperature as high as $4{ }^{\circ} \mathrm{C}$ most of the buds appeared visibly dormant but when dissected dark brown streaks indicated freeze damage (Figure 2a,b). Some buds were still green which indicated that they were healthy [43]. In summary, multiple reports demonstrate a relationship between freeze damage, tree dormancy, and bud phenology during a freeze $[35,44]$. 


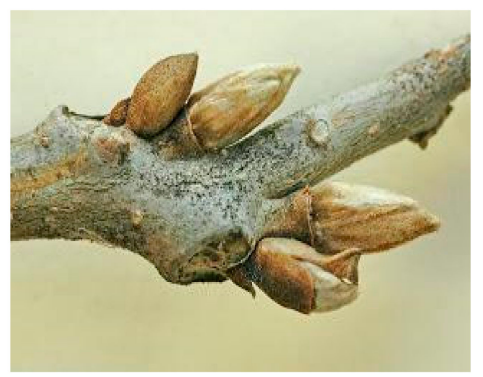

(a)

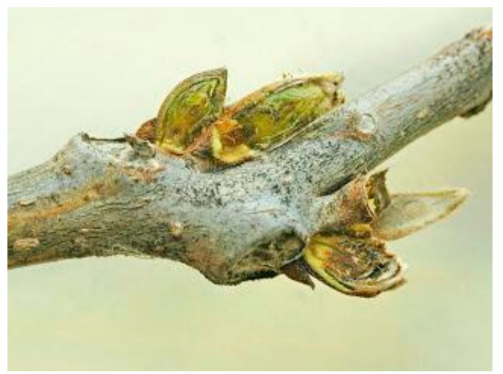

(b)

Figure 2. After low temperature on 16 April 2018 ( $\left.4{ }^{\circ} \mathrm{C}\right)$ : (a) 'Kanza' buds, 20 June 2018; appear to be dormant. (b) Dissection of same 'Kanza' bud with brown streaks indicating freeze injury [43].

\subsubsection{Region and Type of Cultivar}

The native pecan shows a wide diversity in cold tolerance in the different climates of the northern and southern production regions. The northern region native populations are strikingly more resistant to cold damage than native southern region populations [8,17]. Genetic diversity for cold resistance is a dominant factor in the native northern pecan populations [8]. The same is true for the improved cultivars. For example, 'Giles' consistently has less freeze damage than 'Mohawk' when grown within the same region [45]. 'Giles' is a northern-type cultivar. 'Mohawk' a cross between 'Success' and 'Mahan', is of southern origin. The 'Pawnee' and 'Kanza' cultivars, with northern pecan parents had only limited leaf damage in a spring freeze while severe damage was observed in southern pecan cultivars including 'Maramec', 'Oconee', and 'Nacono' (Figure 3) [5]. There are exceptions. The southern region (Mississippi) 'Stuart' is cold hardy. Severe damage to both the southern 'Maramec' and northern, 'Hennings' cultivars was observed after a 15 April spring freeze, 2014 [39] suggesting that cultivar origin is less important than bud stage.

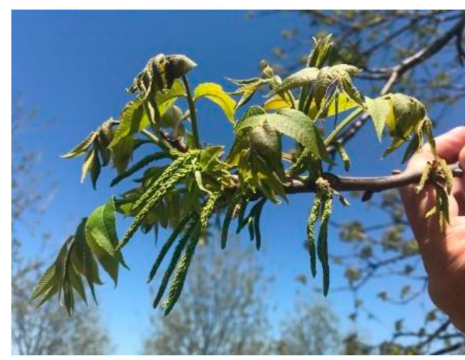

(a)

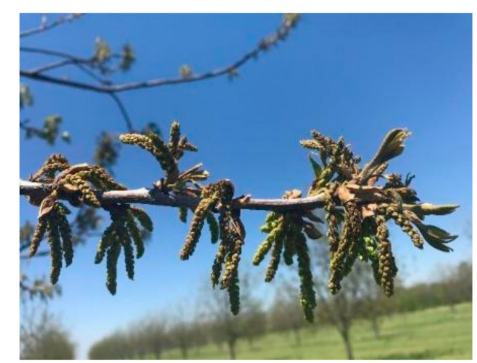

(b)

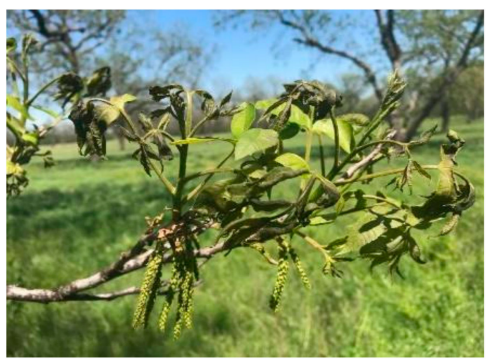

(c)

Figure 3. Variation in freeze damage (15 April 2020) among cultivars: (a) Leaf damage on 'Kanza' pecan. (b) 'Oconee' suffered leaf catkins and terminal bud damage. (c) Improved varieties such as 'Western' had more advanced foliage than some of the native trees and suffered from leaf damage [5]. At the time of this freeze, a number of primary buds at the tip of limbs were already showing the catkins and leaf shoots on improved cultivars (such as 'Western') while some of the native trees were only at bud break stage [5].

Some cultivars show more bud damage as there was no bud enlargement due to dead buds after freeze, such as was observed in 'Faith'. While other cultivars had no freeze injury as buds were healthy and alive, such as 'Hark' [43]. Variable responses to freeze damage have been observed in different cultivars as some cultivars show more bud death or injury as compared to others [36,42,43]. For example, the 'Kiowa' appears to be more susceptible to spring freeze compared to 'Cheyenne', 'Choctaw', and 'Wichita' [36].

The combination of scion and rootstock also significantly alters the impact of freeze injury, which indicates a close relationship between the seedling rootstock's effect on scion phenology and susceptibility to freeze damage [41]. Differences in freeze damage of scions at uniform stages of bud 
growth were apparent at bud swell and leaf burst. At bud swell stage, buds of the 'Candy' (used as scion on different rootstock) cultivar were more damaged than those of ungrafted control seedlings (at the same bud growth stage). In the case of rootstocks, at the inner scale split stage, 'Sioux' seedling was more severely damaged than 'Burkett' seedling. However, rootstock did not show any differences in freeze damage at bud dormant and swell stage [41]. Rootstock with early budding force early growth in scions. 'Stuart' seedlings tend to be late to begin growth in spring, offering some protection from spring freezes. 'Elliott' seedlings (known for excellent nut quality) have early spring growth, making them more susceptible to freeze damage than 'Moore' (rootstock) [46]. 'Elliott' is good when grown in the south, but it is not suitable for winter and spring cold in the north. There are some studies in other nut crops-such as pistachio, walnuts, and almond-in which they compared different rootstocks and cultivars for their resistance and susceptibility to spring frost damage [47-49]. However, in pecan there are relatively few studies that focus on selecting cultivars based on spring freeze traits.

The selection and breeding of early maturing pecan varieties has generated several undesirable traits; as increased susceptibly to freeze damage, poor nut quality, enhancement of irregular fruiting, tree dieback, and premature defoliation. These problems are more predominant in large nut producing varieties such as 'Mohawk', 'Mahan', and 'Success' or in extremely early maturing varieties with moderate nut size such as 'Cherokee', 'Cheyenne', and 'Chickasaw' [8]. The early bud breaking cultivars 'Desirable' and 'Wichita' are also more susceptible to freeze damage than late bud breaking cultivars [17]. Not surprisingly, native cultivars, when grown in their native regions, are less susceptible to freeze damage than improved cultivars. The improved 'Western' cultivar is a good example; as these varieties were at more advanced stage than natives [5]. The susceptibility to late spring freeze is a function of time of bud break. If the cultivars break bud dormancy early during spring, there is a higher chance of freeze damage than the late bud break. Breaking bud dormancy late in spring allows them to escape most of the freeze injury during spring [5,50].

\subsubsection{Upper and Lower Canopy or Tree Height or Size}

Pecan trees can grow to more than $21 \mathrm{~m}$ tall and $12 \mathrm{~m}$ wide. Because of this, temperatures and therefore growth, varies within the canopy. A radiation freeze, one in which temperatures near the soil surface and lower canopy are lower than the temperatures in the upper canopy results in a rising temperature gradient from canopy bottom to top, with more injury to the lower versus the upper canopy, see Figure $4[5,8,37,43,51]$. The variation in freeze injury due to radiation freeze varies upper and lower canopy of same tree and also among different cultivars (Figure 4). The trees at the Red River orchard were much older and more than twice in height than Conrad-'McMillan' orchard trees (with heights less than 30 feet). The extensive damage towards the west along the Red River and in Garvin County was observed, while limited leaf damage in Conrad-'McMillan' orchard [5]. In the lower portion of the canopy, terminal buds were killed and green buds pushed from the base of last year's shoot, while $7.6 \mathrm{~m}$ (25 feet) and higher bud break appeared normal [43,51]. Similarly, a branch only $2.4 \mathrm{~m}$ (8 feet) above the ground with brown and dead catkins was observed and shoots from a limb $6.1 \mathrm{~m}$ (20 feet) from the ground with healthy catkins was observed after 18 April 2020 freeze [37]. Generally, these lower canopy freezing temperatures stunted and killed terminal buds producing abnormal growth on the previous year's branch [52]. This new shoot growth was initiated from the primary buds below the terminal bud (mid portion of shoot) (Figure 5). Similar growth type and flowering was observed in all 15 northern and southern pecan cultivars. Only a few of the new shoots produced pistillate flowers and produced less nuts per cluster, 2 or 3 versus the $4-5$ nuts in a normal cluster [52]. 


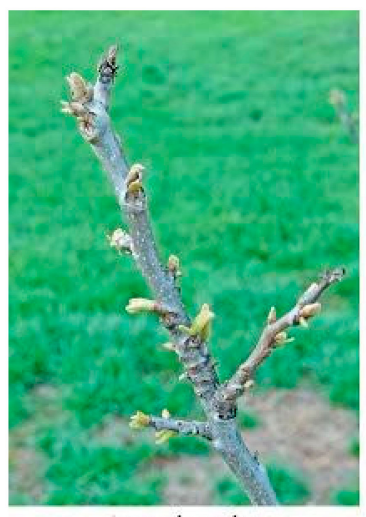

Lower branch

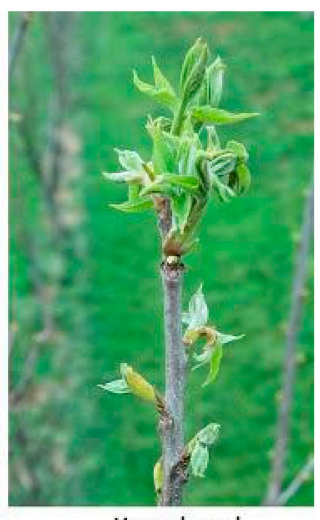

Upper branch

(a)

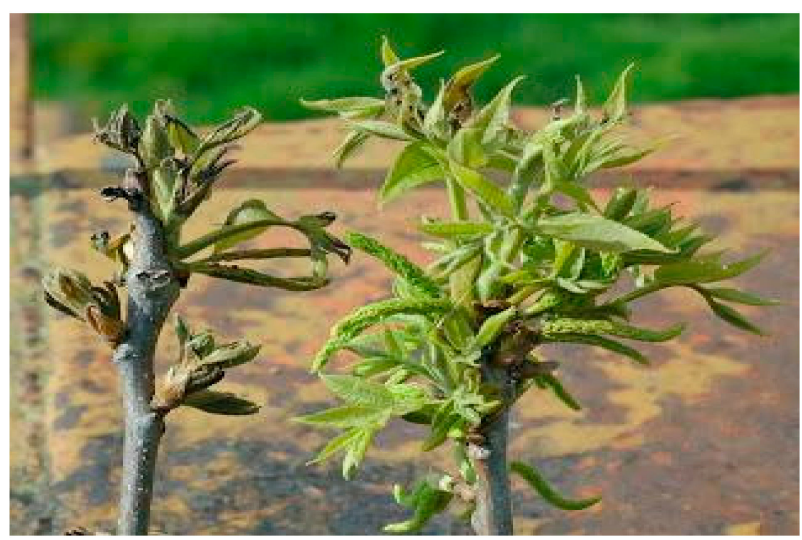

(b)

Figure 4. Effect of radiation freeze (on 16 April 2018) on bud break within same tree: (a) In the lower portion of the canopy (left) and higher (right) [43,51]. (b) A branch only $2.4 \mathrm{~m}$ above the ground (leaf side) and shoot from a limb $6.1 \mathrm{~m}$ from the ground with healthy catkins (right side) (after 18 April 2020 freeze) [37].

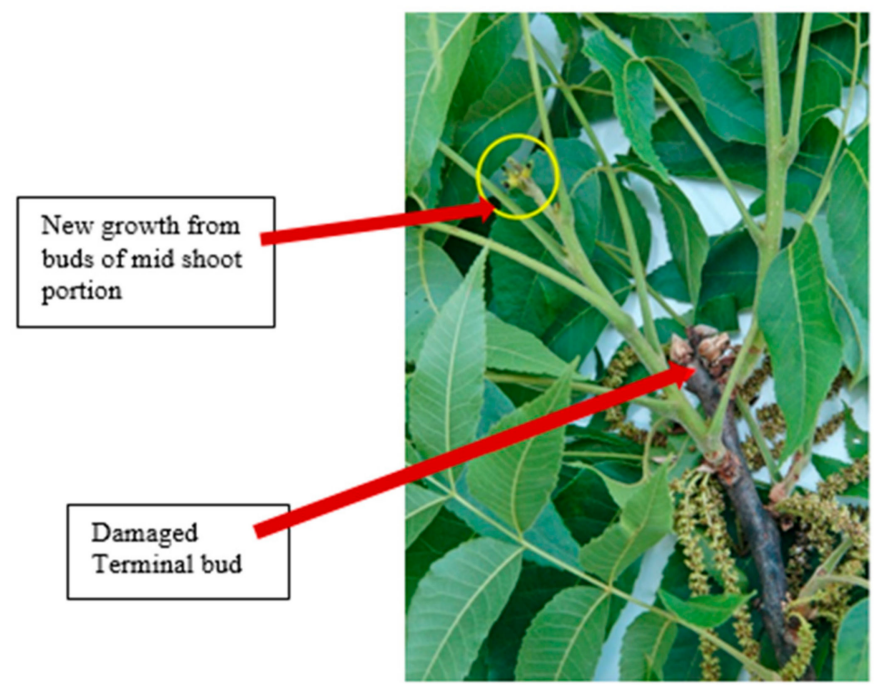

Figure 5. Growth from primary buds below the terminal bud after the terminal bud killed by freeze on 16 April 2018 [52].

\subsubsection{Management Practices}

Management practices—such as pruning, thinning, irrigation, nutrition, etc.-influence frost sensitivity and frost exposure of trees. Canopy structure can either decrease or increase the probability and intensity of freezing. This includes structural arrangement of foliage, including canopy height, length, density, porosity and leaf area index, and individual organs. A dense tree canopy buffers sensitive tissues from adverse weather conditions, reducing the probability and intensity of freezing events (radiative). Pruning (removing woody parts from canopy), thinning (removing either individual or clusters of fruits or flowers), significantly impacts orchard trees. The modification of canopy structure impacts the microclimate by increasing the energy lost by long-wave radiation. Although canopy modification may lower the minimum temperatures during freezing events, removing lower buds can also help avoid frost exposure on the remaining buds in the orchards. The remaining buds, flowers, and fruits are located higher in the tree where the temperatures are warmer. Deciduous trees should not be pruned during the dormant season in cold climates. Punning influences non-structural carbohydrates (NSC) (especially starch content) and this impacts the differentiation of bud meristems and dormancy 
induction and release. The effects of pruning depend greatly on the timing (summer vs. winter). Thinning may influence the role of NSC in winter frost resistance [53].

Artificial irrigation of plants by sprinkling them with cool water can prevent frost damage to flowers by delaying budburst during radiative frosts. Genes involved in the modulation of frost resistance are linked to dehydration-related genes. In the short term, artificial dehydration and drought stress affect water balance and increase frost resistance [53].

Nutrients have complex effects depending on which nutrient is being supplied and when. The relationship between specific nutrients and frost resistance is unclear. Fertilized trees are more vulnerable to frost damage, especially the meristems. Phosphorus, which is involved in cell division, is important for recovery of tissues after freeze damage [53].

\section{Effect of Temperature on Female and Male Flowers}

Temperature stress can cause remarkable defects in the anatomy and function male and female flowers. The male or staminate flowers consist of two parts; anther and filament. The anther contains the male gametophyte, i.e., pollen grains. The female or pistillate flower consists of three parts; stigma, style, and ovary. The ovary contains the ovule which contains the female gametophyte or egg. Once pollen matures and is released from the anther, the pollen grains become wind borne, those reaching the stigma adhere to its surface, germinate producing the pollen tube through which the male gamete travels to fertilize the egg. In trees, interaction between pollen and pistil regulates the progamic phase; the period of pollen tube growth through the pistil from pollination to fertilization, or gamete fusion. Fluctuations in temperature significantly affect each process involved in the progamic phase; stigmatic receptivity, pollen tube germination, and growth and ovule degeneration [54].

\subsection{Effect on Female Flowers}

Female organs have a special mechanism to assist with pollen competition and to differentiate among pollen grains at various steps. In pecan, the stigma's large cone shaped surface with a small diameter and round surface papillae cells make it well suited for wind pollination by enhancing its pollen collection efficiency [8]. In a mature pistillate pecan flower, the stigma surface becomes more prominent and may turn red in some cultivars [55]. The stigma color varies from deep red in the 'Pawnee' and 'Success' to vivid green in the 'Stuart' cultivar. Stigma pollen receptivity can be indicated by the presence of a viscous fluid, by adherence of pollen to the stigma surface and by calculations of stigma drying [31]. In pecan, adherence of pollen to the stigma is considered the only reliable method of evaluating stigma receptivity [55].

The ability of stigma to assist in pollen adhesion and germination is called stigma receptivity; it varies markedly among the plant species. Stigma receptivity has practical implications in agriculture because limiting floral receptivity decreases the effective pollination period and therefore fruit formation and yield [56]. Loss of stigma receptivity occurs in stages; first the ability to support penetration of pollen tubes into the transmitting tissue of stigma surface declines, then the germination of pollen grains slows and finally the adhesion of pollen grains to the stigma fails to occur. The gradual loss of stigmatic receptivity in the three consecutive steps has been reported in pear and sweet cherry $[57,58]$.

Some studies have reported on the influence of temperature on pistillate particularly on the complex pollen-pistil interaction and its susceptibility to temperature changes. In sweet cherries, a $2.8^{\circ} \mathrm{C}$ increase in the mean temperature, from $13.3-16.1^{\circ} \mathrm{C}$ decreased stigma activity in the three consecutive steps described above [58]. The impact of temperature on stigmatic receptivity has been reported in other plant species; peach, cherimoya, sweet cherry [59-61]. Ovule degeneration as a response to temperature has been investigated in plum, sweet cherry, sour cherry, and citrus cultivars [61-64].

There are relatively few studies on the impact of low temperatures on pistillate flowers. The damage to the ovary and whole pistillate flower due to low temperature was observed in almond [44]. The ovarian locule is particularly sensitive to freezing; injury is frequently characterized by cell wall 
thickening, lack of meristematic activity, and destruction of the vascular tissues. At full bloom in apple flowers, thawing first caused brown discoloration at the base of the style, then the damage may extend both to the style and to the ovary, resulting in death of the placenta, abortion of ovules [65]. Similarly, Longstroth [66], observed that sudden spring freezes killed the cherry ovules and whole king flowers (Figure 6). A recent preliminary experiment on pecan flowers, showed that low temperature caused the deformation of stigma papillae cells which are very important for pollen adhesion and germination [67]. We are going to further analyze detailed structure of female and male flowers organs in response to low temperature in our future experiments.

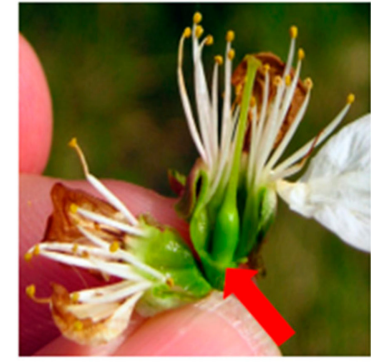

(a)

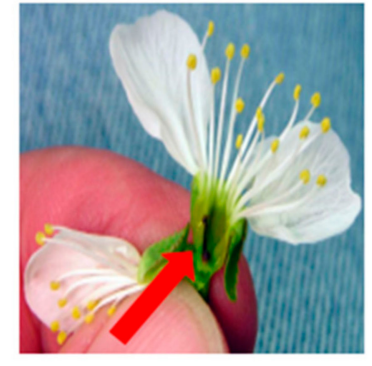

(b)

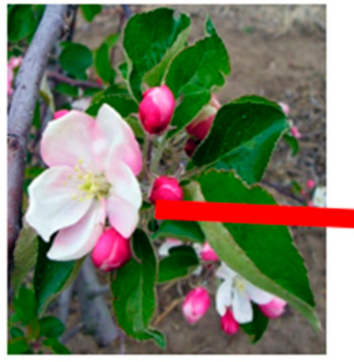

(c)

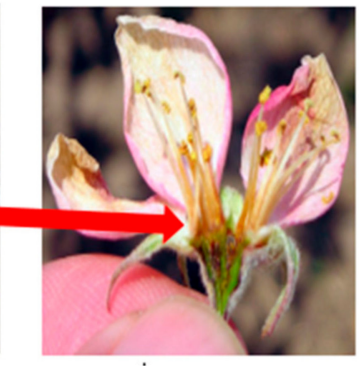

(d)

Figure 6. (a) This cherry flower was not damaged by a freeze the day before. (b) The pistil of this cherry flower was killed by a spring freeze the day before and has shriveled and turned black. (c) The king bloom of the apple flower cluster has opened, but the side blooms are still closed. The king bloom is more susceptible to freeze injury at all stages of the apple bud development in the spring and is often the first flower killed in the cluster. (d) The dark brown center of the flower indicates it was killed by a freeze [66].

\subsection{Effect on Male Flowers}

Low temperatures may reduce the pollen germination and tube growth rate, limiting fertilization [58]. The influence of temperature on pollen performance varies among species and cultivars [68]. In vitro analysis of pistachio pollen germination and pollen tube growth both were severely impaired under $7^{\circ} \mathrm{C}$ and above $41^{\circ} \mathrm{C}$, with $23.9^{\circ} \mathrm{C}$ being the optimum temperature for assessing pollen performance [69] and declines commencing at $25^{\circ} \mathrm{C}$ [70]. However, in apricot and sour cherry even low temperature- $10{ }^{\circ} \mathrm{C}$ and $15^{\circ} \mathrm{C}$, respectively-did not impair the in vivo pollen germination [71,72]. The lowest pollen germination and pollen tube growth rates in apricot and sweet cherry were observed at $5^{\circ} \mathrm{C}$, while in pear pollen germination was reduced below $15^{\circ} \mathrm{C}[73,74]$. Temperature is a factor in filament length after the tight cluster stage in sweet cherry [75]. Pollen performance can be used to identify genotypes resistant to low and high [69]. The optimum temperature for pollen performance varies from one species to another. At $22{ }^{\circ} \mathrm{C}$, almond pollen adhesion and germination is better than at $15^{\circ} \mathrm{C}$ [76].

The effects of spring frost on pollen viability of almonds are highly variable and depend on the characteristics of both the freezing stress and the plant material status. The pollen germination in different almond cultivars after frost treatment has been studied in relation to boron presence and absence [77]. They observed limited pollen growth after $-3{ }^{\circ} \mathrm{C}$ treatment in the absence of boric acid [77]. The range and optimum temperatures for effective pollen germination and pollen tube growth has been studied in other fruit species; papaya, mango (Mangifera indica), and sweet cherry [68,73,78].

Low temperatures also affect the physiology and cellular metabolism of plants and potentially lead to defects in reproductive organs. A disruption of sugar metabolism in the tapetum due to cold stress caused a reduction in energy reserves, disruption of starch and hexose formation for the growth of pollen grains that ultimately induce pollen sterility in rice [79]. The low temperatures downregulate the cell wall gene OSINV4 which is anther-specific and is expressed in the tapetum cell layer at the young microspore stage. This gene later expresses at the binucleate stage in maturing microspores. However, there was no reduction in the expression level of OSIN4 in cold tolerant rice cultivars 
under low temperature and no effect on pollen formation [79]. Delay heading time in rice and flower abnormalities will lead to severe sterility when rice is exposed to cold at flowering [80]. When mitosis I and II in rice was disrupted by low-temperature stress microspore maturation into pollen grains was inhibited [81].

\subsection{Effect on Cell Activities and Gene Regulation}

Extreme high and low temperatures disrupt multiple cellular activities. Extreme temperatures can dramatically change membrane fluidity, nucleic acid and protein structures, and metabolite and osmolyte concentrations [82]. Extreme temperatures precipitate the formation of reactive oxygen species (ROS), which at higher concentrations, will result in oxidative damage and, potentially, cell death [83]. Photosynthesis is also affected by extreme temperatures. Cold reduces carbon dioxide uptake even under high light conditions by damaging the thylakoid electron transport chain, inhibiting rubisco activity, and inducing stomatal closure [84]. The incubation of almond bud flowers in low temperatures affected significantly chlorophyll fluorescence CF for all studied cultivars [50]. Furthermore, this led to reduction in activity of photosystem II [50]. This reduction in photosynthesis results in lower energy reserves for the development of reproductive tissues. The initial response to high and low temperature are similar, changes in membrane fluidity, calcium signaling, mitogen-activated proteins kinases (MAPK) activation, increases in the ROS concentrations, protein simulation, and proteosomal degradation induces transcriptional changes in response to both conditions [85]. However, the final transcriptional reactions are different for high and low-temperature stress. The cold specific transcription factors such as C-repeat binding factors $\mathrm{CBF} /$ dehydration-responsive element-binding (DREB) protein that has domain APETALA2 (AP2) family are involved in response to low temperature stress. These factors induce the expression of late-embryogenesis abundant ( $L E A)$ /cold-regulated (COR) genes [86]. Many of these target genes are thought to encode proteins that increase the freezing tolerance by stabilizing membranes, or increasing the concentration of protective osmolytes in the cells [83]. Many low temperature-induced proteins have one common characteristic, a hydrophilic nature that decreases the impact of cellular dehydration [80].

Genetic engineering is a potential tool for inducing stress tolerance traits. For instance, a protein identified in lily pollen (LLA23) showed expression in Arabidopsis and was successfully used to induce salt and drought tolerance in vegetative tissues [87]. OsAsr1 was highly expressed in transgenic rice plants expressing the C-repeat/dehydration responsive element binding factor 1 (CBF1), suggesting the regulation of OsAsr1 by CBF1 [80]. It has been reported that the cold tolerance of transgenic rice was improved by over expression of the gene OsAsr1 [80]. Whether these and other proteins can be used to improve temperature stress tolerance in pollen has yet to be tested [83]. Despite some studies on the effects of frost damage on the reproductive organs of various Juglandaceae family species, little is known about the molecular regulation and control of low temperature stress. Recently in almond some genes and cold shock proteins (in fully open flower resistant to frost) and cold responsive miRNA was studied in $[44,88]$. These studies might enhance the possibility in finding freeze resistant genes and manipulation to develop cold resistant trees in this family.

\section{Carbohydrates and Flower Bud Formation}

Carbohydrates are stored in both soluble and insoluble form. However, in trees, especially roots, they are stored as insoluble starch [89]. In other plant parts, soluble carbohydrates are stored as sorbitol, a major plant component (sugar alcohol) along with fructose, glucose, sucrose [89]. The seasonal variations in carbohydrate accumulation has been studied in many tree species. Almost all temperate deciduous tree species are characterized by high carbohydrate reserves in late autumn and winter, later utilized during spring growth, then gradually accumulation again during the summer and early autumn [90,91]. Wood [92] hypothesized that a pecan terminal may not be able to initiate female flowers without sufficient carbohydrates. He also proposed that a threshold amount of accumulated carbohydrates and a sufficient amount of endogenous phytohormones regulates a complex mechanism 
of flower initiation. The carbohydrates such as starch, sucrose and glucose play an important role in signaling and energy in floral induction across various flowering pathways [93]. As the flower induction stage begins in spring, stored carbohydrates especially those from roots work as substrate for flower development [94].

As with all fruiting trees the pecan tree's metabolic state, the carbohydrates, phytohormones, and mineral composition, are key factors in the induction, initiation, and differentiation of buds into flowers, bloom, pollination, and fruit set. Two theories- "carbohydrate theory" and "phytohormone theory"-were suggested by Barnet and Mielke [95], which proposed the role of carbohydrates and hormones (respectively) in the flowering of pecan. These theories were later redefined by Wood et al. [96] after studying the pecan. Wood et al. [96] proposed that regulation of flowering in pecan is a two-step process, with the first step relying on hormones produced by the fruit and shoots (including foliage) and the second step relying on the size of the dormant season's available carbohydrate reserves at bud break. Wood [9] later revised this theory to include a third factor. In his three-phase theory, the first stage is regulated by florigen (flowering hormone which controls flowering) with the FLOWERING LOCUS T (FT) protein acting as a long-distance signal. The second and third phases are then regulated by hormones and carbohydrates. In Arabidopsis thaliana, activation of $F T$ gene by CONSTANS (CO) protein in response to inductive photoperiod during spring required activity by trehalose-6-phosphate synthase 1 (TPS1) as well as high carbohydrate content as a physiological signal [97]. The carbohydrate (starch, sucrose, etc.) level in roots, shoots, branches, wood and leaves of various trees such as pistachio (Pistacia vera L.), chestnut (Castanea sativa), pear, orange, peach, apple, pecan, olive, and walnut have been studied with varying degrees of linkage to flowering $[90,98,99]$.

Starch levels are significantly decreased by the increased activity of starch degrading enzymes in the parenchyma cells at the onset of bud development [93]. Similar findings were reported by Smith and Waugh [90] in pecan, who found the rapid decrease in starch content at bloom time and nut filling indicates its significance in flowering and fruiting of pecan. Smith and Waugh [90] analyzed the starch, non-reducing and reducing sugars for two consecutive years to examine their variations in relation to different growth stages of pecan. The reducing sugars which are considered as labile forms of carbohydrates, were in low concentration and show no seasonal fluctuations [90]. In apple, the genes involved in starch biosynthesis showed less expression in 'Qinguan', a profusely flowering cultivar than in 'Nagafu No. 2', s weakly flowering cultivar while starch degrading genes showed the opposite pattern [93]. Developmental processes, especially flowering, are affected by genetic mutation related to key enzymes of sugars and starch metabolism; for example, HEXOKINASE1 (HXK1) and PHOSPHOGLUCOMUTASE1 (PGM1) genes (in A. thaliana) [97]. Particularly, TPS1 which acts as a 'central hub of carbon signaling' plays critical role in transition of flowers by controlling the expression of key floral integrators in shoot apical meristem (SAM) and leaves [97]. The mutation or loss in function of TPS1 reported the slow plant growth, infertile flowering from shoot apical meristem, and axillary stem simultaneously or no flowering, even under sufficient photoperiod [97]. The alpha, alpha-trehalose-phosphate synthase gene is a key gene of the trehalose biosynthetic pathway, associated with cold acclimation, which was downregulated at post-thawing in almond [44]. Downregulation of trehalose-6-phosphate phosphatase gene during de-acclimation and accumulation of trehalose occurs during cold acclimation has been observed in A. thaliana [100,101].

Chen et al. [93] analyzed three flower bud stages of apple varieties for RNA sequencing-based transcriptomic profiling while investigating the mechanisms of floral induction. Total sugars, glucose, sucrose and sorbitol concentration in buds during floral induction (all three floral bud stages) was significantly higher in 'Qinguan' a profusely flowering cultivar than in 'Nagafu No. 2', a weakly flowering. Fructose in the early stage and starch at later stage was higher in 'Nagafu No. 2'. A significant difference in gene expression linked to carbohydrates has been found in 'Qinguan', a profusely flowering cultivar and 'Nagafu No. 2' a weakly flowering cultivar. In Qinguan, 5 genes related to the conversion of glucose to glycerol-3-phosphate and 1 (FRK) fructose biosynthesis gene showed significantly higher expression than Nagafu No. 2 [93]. In pecan, the transcriptomic analysis of three bud and two flowering 
stages was performed by Wang et al. [102] to understand pathways involved in female flowering. The downregulation or no expression of key enzymes, i.e., sucrose synthase (SUS) and sucrose phosphate synthase (SPS) of sucrose biosynthesis indicates the slow formation of sucrose during the development of flower organs from a flower bud. They reported expression of 16 genes, including 10 SUS, 5 SPS, and 1 sucrose transporter synthase (INV) gene related to sugar metabolism pathways in pecan [102]. In buds the sugar content is significantly greater than starch content. Sucrose and its hydrolysis products strongly contribute to increased sugars during corolla expansion and to osmotic potential. This is analogous with the demonstration in cotton that floral bud growth of cotton, a rapid increase in import of sucrose and its hydrolysis products support the bud expansion by decreasing the water potential of bud tissue [103].

\subsection{Carbohydrate Transport}

Spring bud development is a critical phenological process closely linked to environmental factors; vernalization, photoperiod, and precipitation. During spring, bud growth depends on long-distance transport of remotely stored carbohydrates in shoots and roots. Rapid and efficient mobilization of stored carbohydrates is necessary to sustain the bud growth after bud break [104].

During spring, soluble carbohydrates increase in the xylem sap of walnut, maple, grapevine, willow, and pear $[105,106]$, suggesting xylem plays a critical role in the translocation of these metabolites during bud break and development. In walnut (Juglans sp.), for example, the starch-degrading enzyme activity and co-transport of sucrose in parenchyma cells coincides with bud break and growth initiation [107]. The reduction of sugars and starch in storage organs can be linked to the increase in soluble sugars in buds, which supports bud break as well as flowering [104]. The sugars will eventually be exported transporter (SWEET) and sucrose uptake carrier (SUC) also known as sucrose uptake transporter (SUT) proteins family act collectively to upload Suc (Sucrose) and Hexoses from mature leaf parenchyma cells into phloem [108]. In A. thaliana leaves, SWEET11 and SWEET12 proteins export SUC from parenchyma cells to SUT1 for phloem loading [108].

The loading/unloading dynamics of carbohydrates along phloem length produce the concentration gradient which generates the munch flow in phloem [109]. Interestingly, phloem transport capacity has been reported to be blocked during winter. However, the activity in the thin layer of phloem near the cambium and its role in translocation of carbohydrates during and after bud dormancy has also been reported, suggesting there is winter phloem transport [110]. Phloem sieve tubes have been reported as remaining active in $J$. regia at temperatures below $-10{ }^{\circ} \mathrm{C}[110,111]$ suggesting that the phloem is involved in long-distance transport of remotely stored carbohydrates during bud growth and that phloem interruption affects xylem transport. These results suggest that xylem transports carbohydrates and that this transport is maintained by phloem munch flow. They further suggest bud growth is supported by the carbohydrates concentrated near the shoot apex, as well as those transported by the vascular system. Impeding nonstructural carbohydrates (NSC) delivery to apical buds by girdling reduces total NSC proximal and available near apical bud, retarding bud growth.

\subsection{Carbohydrates Reserves}

Carbohydrates constitute the tree's major reserves used during bud break. In pecan, staminate flower development relies on the carbohydrate reserves from the previous two seasons, while pistillate flower development relies only on the previous season's reserves [94]. Witzstein and Sparks [31] suggested that the degree of flower formation is determined by the carbohydrates reserve in storage tissues during previous season. The terminal position of the female inflorescence on the shoot may or impede its bud development, bloom, and set when carbohydrates reserves are low. Yates and Sparks [112] analyzed the aborted and non-aborted pecan flowers. Their findings support the earlier hypothesis (by $[113,114]$ ) that drop I in pecan is associated with underdeveloped flowers. There is a positive correlation between the number of pistillate flowers in the spike and shoot vigor [112]. This is consistent with the report that a reduced number of inflorescences per shoot on high node grapevine was 
associated with reduced carbohydrate reserves and reduced shoot vigor [115]. Flowers per inflorescence were reduced by as much $50 \%$ in response to lower overwintering carbohydrate reserves [115].

Smith et al. [3] demonstrated that the cold injury harmed the return fruit set of Mohawk more than that of Giles. This suggests the poor return fruit set of 'Mohawk' versus 'Giles' and is a function of the greater carbohydrate demand in 'Mohawk' to develop its larger fruit.

\subsection{Carbohydrate and Temperature}

Carbohydrates storage in roots is affected by temperature, light intensity, and defoliation. Tromp [89] reported increased temperature changes cause a loss of sugar and starch in apple roots. When stressed trees experienced $-5{ }^{\circ} \mathrm{C}$ in mid-March the observed reduction in the pattern of carbohydrate reserves in related shoots was consistent with the bottom to top canopy gradient in bud death and reduced shoot and foliage growth. The concentration of total free sugars and starch in previous season's shoots was $\approx 41 \%$ of normal in declining trees and $\approx 5 \%$ of normal in dead trees. Starch showed a similar trend, with shoots from declining trees containing $\approx 62 \%$ of the normal concentration, whereas those of dead trees contained $41 \%$ of normal. The shoots and roots of dead and severely declining trees had little or no free sugars or starches, even though there had been little or no new vegetative growth to consume photo-assimilate reserves from either tissue [20].

Spring frost susceptibility or tolerance depends on flower sugar content [65]. There are some other studies also suggesting similar results for a relationship between frost hardiness and sugar content (glucose, fructose, sucrose) [16,24]. During cold stress, sugar content in buds showed an enhancement and this accumulation may be due to sugar translocation from shoots and bark to the buds. Sugar reduction in shoots is related to the improved capacity of buds against cold stress [116]. Accumulation of sugars, saccharides, proteins, and osmotic regulators (such as proline) improved cold tolerance in pistachio [117]. Carbohydrates—such as sucrose, sorbitol, and raffinose-are subunits of plant protective units. Sugars have a significant role in reducing the freezing temperature of cell water, providing accessible energy and protecting the protein's structure and action against cold stress [118]. Maximum cold tolerance of the 'Khanjari' cultivar was a result of sugar existence during the bud swelling stage. Sugar accumulation under low temperature is an important factor, so that superficial reduction in sugar content as a result of spring breathing caused reduction in cold tolerance. Through the enhancement of the sugar content ice formation decreased and ice-induced dehydration prevented [119]. Increased frost hardiness was observed with increased carbohydrate content (glucose, fructose, sucrose) in walnut [119]. The high GFS concentration can decrease freeze temperature (but only to $1-2{ }^{\circ} \mathrm{C}$ ) [119]. This increase in soluble carbohydrates is usually related to hardening [119]. Soluble sugars increase followed by a starch decrease, resulting in acclimation of trees to winter and spring cold [24].

\section{Conclusions}

In conclusion, the impacts of spring freezes-from minor to severe-on pecan buds and flowers is well documented. A sudden freeze for less than a few hours that kills the terminal buds precipitates new shoot growth from secondary or even tertiary buds. However, the pistillate flower formations from secondary buds are much fewer than those from the primary buds. The degree of spring freeze injury varies by temperature, time of freeze, cultivar and origin, stage of bud growth and tree size. Spring freezes damage the reproductive organ function and structure; pollen viability, pollen germination and adhesion, ovule viability, stigma receptivity, lowering the effective pollination period and fertilization. Susceptibility and resistance to cold varies among pecan cultivars. These genetic differences manifest as regulation of sugar, starch and other carbohydrate contents during flower initiation and bud break. Genetic diversity of pecan has been documented with different molecular markers; inter-simple sequence repeat (ISSR), simple sequence repeat (SSR), and transcriptomic studies using RNA sequencing but has not produced definitive results that can be used in a plant improvement program. Information on how low temperatures affect the structure and function of staminate and 
pistillate flowers parts is limited. However, as the climate changes, spring temperatures rise earlier and are punctuated by erratic freezes, leading to earlier and more cold susceptible bloom, spring freeze damage will remain a problem for pecan producers. Therefore, the pecan plant breeder needs to focus on developing new varieties which are resistant to spring freeze as well as other types of freezing; as some pecan cultivars are resistant to winter freeze but they can be damaged by spring freeze or low temperature. Our recent experiments showed that even temperatures above freezing $\left(0^{\circ} \mathrm{C}\right) \mathrm{can}$ cause significant damage to both male and female pecan flowers. Therefore, breeders and farmers may consider selecting cultivars, rootstock, along with site by their spring freeze resistance, time of bud break, etc. Genetics could be a good tool for making resistant cultivars.

Funding: Oklahoma Department of Agriculture, Food, \& Forestry Specialty Crop Grant Program funded project: "Flowering Management: Minimizing the Harms Caused by Spring Freeze in Pecans".

Acknowledgments: The work was supported by Oklahoma Department of Agriculture, Food, \& Forestry Specialty Crop Grant Program and Oklahoma Pecan Growers' Association.

Conflicts of Interest: The authors declare no conflict of interest.

\section{References}

1. Kuden, A.B.; Tuzcu, O.; Bayazit, S.; Yildirim, B.; Imrak, B. Studies on the chilling requirements of pecan nut (Carya illionensis Koch) cultivars. Afr. J. Agric. Res. 2013, 8, 3159-3165.

2. Anderson, P.C. The pecan tree. In Horticultural Sciences Department, UF/IFAS Extension; Guide-HS982; University of Florida: Gainesville, FL, USA, 2019; pp. 1-16. Available online: https://edis.ifas.ufl.edu/hs229 (accessed on 26 October 2020).

3. Sparks, D. Chilling and Heating Model for Pecan Budbreak. J. Am. Soc. Hort. Sci. 1993, 118, 29-35. [CrossRef]

4. Barison, F.R. Pecan Culture; The Texas Pecan Growers Association: College Station, TX, USA, 1986; Chapter 2, p. 27.

5. Graham, C. What the Recent Freeze Means for Pecan Growers. Noble Research Institute-Noble Farm Damage Report. 2020. Available online: https://www.noble.org/blog/what-the-recent-freeze-means-forpecan-growers/ (accessed on 25 September 2020).

6. Herrera, E. Flowering Habits of Pecan Trees; Guide H-622; Cooperative extension services, New Mexico State University: Las Cruces, NM, USA, 1999; pp. 1-4.

7. Carroll, B.; Smith, M.W. Pecan Varieties for Oklahoma.Division of Agricultural Sciences and Natural Resources, Oklahoma State University, 2017, HLA6201. Available online: https://extension.okstate.edu/factsheets/pecan-varieties-for-oklahoma.html (accessed on 25 September 2020).

8. Sparks, D. Adaptability of pecan as a species. HortScience 2005, 40, 1175-1189. [CrossRef]

9. Wood, B.W. Influence of Plant Bioregulators on Pecan Flowering and Implications for Regulation of Pistillate Flower Initiation. HortScience 2011, 46, 870-877. [CrossRef]

10. Han, M.; Peng, F.; Marshall, P. Pecan phenology in Southeastern China. Ann. Appl. Biol. 2018, 172, $160-169$. [CrossRef]

11. Mesonet. Available online: https://www.mesonet.org/ (accessed on 26 October 2020).

12. Lhotka, O.; Brönnimann, S. Possible Increase of Vegetation Exposure to Spring Frost under Climate Change in Switzerland. Atmosphere 2020, 11, 391. [CrossRef]

13. Gu, L.; Hanson, P.J.; Post, W.M.; Kaiser, D.P.; Yang, B.; Nemani, R.; Pallardy, S.G.; Meyers, T. The 2007 Eastern US Spring Freeze: Increased Cold Damage in a Warming World. BioScience 2008, 58, 253-262. [CrossRef]

14. Cannell, M.G.R.; Smith, R.I. Climatic warming, spring budburst and frost damage on trees. J. Appl. Ecol. 1986, 23, 177-191. [CrossRef]

15. Kim, Y.; Kimballa, J.S.; Didan, K.; Henebry, G.M. Responses of vegetation growth and productivity to spring climate indicators in the conterminous United States derived from satellite remote sensing data fusion. Agric. For. Meteorol. 2014, 194, 132-143. [CrossRef]

16. Smith, M.W.; Reid, W.; Carroll, B.; Cheary, B. Mechanical fruit thinning influences fruit quality, yield, return fruit set, and cold injury of pecan. HortScience 1993, 28, 1081-1084. [CrossRef]

17. Cade, J.C. The Relationship between Fatty Acid Content and Pecan Cold Hardiness; Mississippi State: Starkville, MS, USA, 2001. 
18. Wood, B.W. Cold injury susceptibility of pecan as influenced by cultivar, carbohydrates, and crop load. HortScience 1986, 21, 285-286.

19. Malstrom, H.L.; Jones, J.R.; Riley, T.D. Influence of freeze damage on fruitfulness of the pecan. Pecan Q. 1982, $16,13-17$.

20. Wood, B.W.; Reilly, C.C. Atypical Symptoms of Cold Damage to Pecan. HortScience 2001, 36, $298-301$. [CrossRef]

21. Smith, M.W. Damage by early autumn freeze varies with pecan cultivars. HortScience 2002, 37, $398-401$. [CrossRef]

22. Sparks, D.; Payne, J.A.; Horton, B.D. Effect of subfreezing temperatures on bud break of pecan. HortScience 1976, 11, 415-416.

23. Sparks, D.; Payne, J.A. Winter injury in pecans: A review. Pecan South 1978, 5, 56-88.

24. Farokhzad, A.; Nobakht, S.; Alahveran, A.; Sarkhosh, A.; Mohseniazar, M. Biochemical changes in terminal buds of three different walnut (Juglans regia L.) genotypes during dormancy break. Biochem. Syst. Ecol. 2018, 76, 52-57. [CrossRef]

25. Hentschel, R. Chilling Hours Help Break Spring Dormancy. Illionois Extension. 2020. Available online: https: //extension.illinois.edu/blogs/over-garden-fence/2020-03-09-chilling-hours-help-break-spring-dormancy (accessed on 25 September 2020).

26. Melke, A. The Physiology of Chilling Temperature Requirements for Dormancy Release and Bud-break in Temperate Fruit Trees Grown at Mild Winter Tropical Climate. J. Plant Stud. 2015, 4, 110-156. [CrossRef]

27. Augspurger, C.K. Spring 2007 warmth and frost: Phenology, damage and refoliation in a temperate deciduous forest. Funct. Ecol. 2009, 23, 1031-1039. [CrossRef]

28. Botany. Available online: http://pecan.okstate.edu/html/introduction/id_2.htm (accessed on 25 September 2020).

29. Stein, L.A. Rebounding from the Freeze; Texas Cooperative Extension, Texas A\&M University: College Station, TX, USA, 2003. Available online: https://aggie-horticulture.tamu.edu/newsletters/hortupdate/hortupdate_ archives/2003/jun03/art4jun.html (accessed on 25 September 2020).

30. Spark, D. Abnormal Flowering in Pecan Associated with Freezing Temperature. HortScience 1992, 27, 801-803. [CrossRef]

31. Wetzstein, H.Y.; Sparks, D. Horticultural Reviews, Flowering in Pecan; Department of Horticulture, University of Georgia: Athens, GA, USA, 1986; Chapter 6; pp. 217-255.

32. Woodroof, J.G.; Woddroof, N.C. Abnormalities in pecan. J. Hered. 1930, 21, 39-44. [CrossRef]

33. Cole, J.R.; Hunter, J.H. Abnormal flowering of pecans following freeze damage in 1965. Plant Dis. Rep. 1965, 49, 146-147.

34. Hagler, T.H. Freeze injury to pecans in Alabama. Proc. Southeast. Pecan Grow. Assoc. 1956, 49, 9.

35. Wells, M.L. Response of 'Desirable' and 'Kiowa' Pecan to a Late-spring Freeze. HortTechnology 2008, 18, 455-459. [CrossRef]

36. Madden, G. Late spring freeze in a pecan nursery as a function of variety. Pecan Q. 1980, 14, 11.

37. Reid, W. Spring Frost Burns Emerging Pecan Shoots. Northern Pecans. 2020. Available online: http: //northernpecans.blogspot.com/2020/04/spring-frost-burns-emerging-pecan-shoots.html (accessed on 25 September 2020).

38. Parker, M.; Sorensen, K.; Brock, J. Growing Pecans in North Carolina. North Carolina Cooperative Extension Service. 2016, pp. 1-16. Available online: http://content.ces.ncsu.edu/growing-pecans-in-north-carolina (accessed on 25 September 2020).

39. Reid, W. Freezing Temperatures Injure Emerging Pecan Buds. Northern Pecans. 2014. Available online: http://northernpecans.blogspot.com/2014/04/pecan-trees-restart-growth-after-frost.html (accessed on 25 September 2020).

40. Wells, L. Nutritional, Environmental, and Cultural Disorders of Pecan. B 1332, 2007, 1-11, Cooperative Extension, University of Georgia. Available online: https://athenaeum.libs.uga.edu/bitstream/handle/10724/ 12340/B1332.pdf?sequence=1 (accessed on 17 October 2020).

41. Grauke, L.J.; Pratt, J.W. Pecan Bud Growth and Freeze Damage are Influenced by Rootstock. J. Am. Soc. Hortic. Sci. 1992, 117, 404-406. [CrossRef]

42. Smith, M.W.; Cheary, B.S. Pecan bud damage caused by freezing temperatures during spring 2009 was affected by cultivars. J. Am. Pomol. Soc. 2010, 64, 92-100. 
43. Reid, W. Freeze Injury to Pecan Buds. Northern Pecans. 2018. Available online: http://northernpecans. blogspot.com/2018/04/ (accessed on 25 September 2020).

44. Hosseinpour, B.; Sepahvand, S.; Aliabad, K.K.; Bakhtiarizadeh, M.R.; Imani, A.; Assareh, R.; Salami, S.A. Transcriptome profiling of fully open flowers in a frost-tolerant almond genotype in response to freezing stress. Mol. Genet. Genom. 2018, 293, 151-163. [CrossRef]

45. Smith, M.W.; Gallott, J.C. Mechanical thinning of pecan fruits. HortScience 1990, 25, 414-416. [CrossRef]

46. Grauke, L.J. Family Trees: Roots and Resilience. Pecan South Magazine. 2019. Available online: https: //www.pecansouthmagazine.com/magazine/article/family-trees-roots-resilience/ (accessed on 25 September 2020).

47. Sorkhan, R.S.; Enteshari, S.; Hokmabadi, H.; Tajabadipour, A. Physiological Evaluation of Pistachio Frost Damage Resistant Rootstocks. Int. J. Nuts Relat. Sci. 2011, 2, 55-66.

48. Khadivi, A.; Montazeran, A.; Yadegari, P. Superior spring frost resistant walnut (Juglans regia L.) genotypes identified among mature seedling origin trees. Sci. Hortic. 2019, 253, 147-153. [CrossRef]

49. Imani, A.; Mahamadkhani, Y. Characteristics of Almond Selections in Relation to Late Frost Spring. Int. J. Nuts Relat. Sci. 2011, 2, 31-34.

50. Sakar, E.H.; Yamani, M.E.; Rharrabti, Y. Frost Susceptibility of Five Almond [Prunus dulcis (mill.) D.A. Webb] Cultivars Grown in North-Eastern Morocco as Revealed by Chlorophyll Fluorescence. Int. J. Fruit Sci. 2017, 17, 415-422. [CrossRef]

51. Reid, W. Bud Break after Early April Freezes. Northern Pecans. 2018. Available online: http://northernpecans. blogspot.com/2018/05/bud-break-after-early-april-freezes.html (accessed on 25 September 2020).

52. Reid, W. Nut Set after a Late Spring Freeze. Northern Pecans. 2018. Available online: http://northernpecans. blogspot.com/2018/05/nut-set-after-late-spring-freeze.html (accessed on 25 September 2020).

53. Charrier, G.; Ngao, J.; Saudreau, M.; Améglio, T. Effects of environmental factors and management practices on microclimate, winter physiology, and frost resistance in trees. Front. Plant Sci. 2015, 6, 259. [CrossRef]

54. Hedhly, A. Sensitivity of flowering plant gametophytes to temperature fluctuations. Environ. Exp. Bot. 2011, 74, 9-16. [CrossRef]

55. Grauke, L.J. Pecan Flowering. Available online: https://cgru.usda.gov/carya/Manual/flowering.html (accessed on 25 September 2020).

56. Sanzol, J.; Herrero, M. The effective pollination period in fruit trees. Sci. Hortic. 2001, 90, 1-17. [CrossRef]

57. Sanzol, J.; Rallo, P.; Herrero, M. Asynchronous development of stigmatic receptivity in the pear (Pyrus communis L. Rosaceae) flower. Am. J. Bot. 2003, 90, 78-84. [CrossRef]

58. Hedhly, A.; Hormaza, J.I.; Herrero, M. The effect of temperature on stigmatic receptivity in sweet cherry (Prunus avium L.). Plant Cell Environ. 2003, 26, 1673-1680. [CrossRef]

59. Hedhly, A.; Hormaza, J.I.; Herrero, M. The effect of temperature on pollen germination, pollen tube growth, and stigmatic receptivity in peach. Plant Biol. 2005, 7, 476-483. [CrossRef]

60. Lora, J.; Herrero, M.; Hormaza, J.I. Stigmatic receptivity in a dichogamous early divergent angiosperm species, Annona cherimola (Annonaceae): Influence of temperature and humidity. Am. J. Bot. 2011, 98, 265-274. [CrossRef] [PubMed]

61. Zhang, L.; Ferguson, L.; Whiting, M. Temperature effects on pistil viability and fruit set in sweet cherry. Sci. Hortic. 2018, 241, 8-17. [CrossRef]

62. Beppu, K.; Suehara, T.; Kataoka, I. Embryo sac development and fruit set of "Satohnishiki" sweet cherry as affected by temperature, GA3 and paclobutrazol. J. Jpn. Soc. Hortic. Sci. 2001, 70, 157-162. [CrossRef]

63. Postweiler, K.; Stösser, R.; Anvari, S.F. The effect of different temperatures on the viability of ovules in cherries. Sci. Hortic. 1985, 25, 235-239. [CrossRef]

64. Montalta, R.; Cuencab, J.; Vivesa, M.C.; Navarroa, L.; Ollitraultc, P.; Alezab, P. Influence of temperature on the progamic phase in Citrus. Environ. Exp. Bot. 2019, 166, 1-11. [CrossRef]

65. Rodrigo, J. Review: Spring frosts in deciduous fruit trees-morphological damage and flower hardiness. Sci. Hortic. 2000, 85, 155-173. [CrossRef]

66. Longstroth, M. Assessing Frost and Freeze Damage to Flowers and Buds of Fruit Trees. Michigan State University Extension 2013. Available online: https:/www.canr.msu.edu/news/assessing_frost_and_freeze_ damage_to_flowers_and_buds_of_fruit_trees (accessed on 29 September 2020). 
67. Kaur, A.; Zhang, L.; Maness, N.; Moss, J. The Impact of Temperature on the Development of Pecan Flowers. HortScience 2020, 55, S293. Available online: https://journals.ashs.org/hortsci/view/journals/hortsci/55/9S/ article-pS1.xml (accessed on 26 October 2020).

68. Sukhvibul, N.; Whiley, A.W.; Vithanage, V.; Smith, M.K.; Doogan, V.J.; Hetherington, S.E. Effect of temperature on pollen germination and pollen tube growth of four cultivars of mango (Mangifera indica L). J. Hortic. Sci. Biotechnol. 2000, 75, 64-68. [CrossRef]

69. Acar, I.; Kakani, V.G. The effects of temperature on in vitro pollen germination and pollen tube growth of Pistacia spp. Sci. Hortic. 2010, 25, 569-572. [CrossRef]

70. Therios, I.N.; Trisakoglou, V.M.; Dimossi-Theriou, K.N. Physiological aspects of pistachio (Pistacia vera L) pollen germination. Riv. Ortoflorofruttic. Ital. 1985, 69, 161-170.

71. Austin, P.T.; Hewett, E.W.; Noiton, D.; Plummer, J.A. Self-incompatibility and temperature affect pollen tube growth in Sundrop apricot (Prunus armerica L). J. Hortic. Sci. Biotechnol. 1998, 73, 375-386. [CrossRef]

72. Cerovic, R.; Ruzic, D. Pollen tube growth in sour cherry (Prunus cerasus L) at different temperatures. J. Hortic. Sci. 1992, 67, 333-340. [CrossRef]

73. Pirlak, L. The effects of temperature on pollen germination and pollen tube growth of apricot and sweet cherry. Gartenbauwissenschaft 2002, 67, 61-64.

74. Vasilakakis, M.; Porlingis, I.C. Effect of temperature on pollen germination, pollen tube growth, effective pollination period, and fruit set of pear. Hortic. Sci. 1985, 20, 733-735.

75. Zhang, L.; Ampatzidis, Y.; Whiting, M. Sweet cherry floral organ size varies with genotype and temperature. Sci. Hortic. 2015, 182, 156-164. [CrossRef]

76. Vezvaei, A. Pollen tube growth in Nonpareil almond in relation to pollen genotype, temperature and competition among mixed pollen. Acta Hortic. 1997, 470, 251-261. [CrossRef]

77. Moheb, M.B.; Imani, A.; Shamili, M. Effects of Boron and Cold Stress on Germination of Almond Pollen in Vitro Culture. J. Nuts 2016, 7, 149-159.

78. Cohen, E.; Lavi, U.; Spiegel, R. Papaya pollen viability and storage. Sci. Hortic. 1989, 40, 317-324. [CrossRef]

79. Oliver, S.N.; Dongen, V.J.T.; Alfred, S.C.; Mamun, E.A.; Zhao, X.; Saini, H.S.; Fernandes, S.F.; Blanchard, C.L.; Sutton, B.G.; Geigenberger, P.; et al. Cold-induced repression of the rice anther-specific cell wall invertase gene OSINV4 is correlated with sucrose accumulation and pollen sterility. Plant Cell Environ. 2015, 28, 1534-1551. [CrossRef]

80. Kim, S.J.; Lee, S.C.; Hong, S.K.; An, K.; An, G.; Kim, S.R. Ectopic expression of a cold-responsive OsAsr1 cDNA gives enhanced cold tolerance in transgenic rice plants. Mol. Cells 2009, 27, 449-458. [CrossRef]

81. Satake, T.; Hayase, H. Male sterility caused by cooling treatment at the young microspore stage in rice plants. V. Estimation of pollen developmental stage and the most sensitive stage to coolness. Proc. Crop Sci. Soc. Jpn. 1970, 39, 468-473. [CrossRef]

82. Chinnusamy, V.; Zhu, J.; Zhu, J.K. Cold stress regulation of gene expression in plants. Trends Plant Sci. 2007, 12, 444-451. [CrossRef]

83. Zinn, K.E.; Tunc-Ozdemir, M.; Harper, J.F. Review paper Temperature stress and plant sexual reproduction: Uncovering the weakest links. J. Exp. Bot. 2010, 61, 1959-1968. [CrossRef] [PubMed]

84. Allen, D.J.; Ort, D.R. Impacts of chilling temperatures on photosynthesis in warm-climate plants. Trends Plant Sci. 2001, 6, 36-42. [CrossRef]

85. Zhu, J.K. Abiotic stress signaling and responses in plants. Cell 2016, 167, 313-324. [CrossRef] [PubMed]

86. Thomashow, M.F. Plant cold acclimation: Freezing tolerance genes and regulatory mechanisms. Annu. Rev. Plant Physiol. Plant Mol. Biol. 1999, 50, 571-599. [CrossRef] [PubMed]

87. Yang, C.Y.; Chen, Y.C.; Jauh, G.Y.; Wang, C.S. A lily ASR protein involves abscisic acid signalling and confers drought and salt resistance in Arabidopsis. Plant Physiol. 2005, 139, 836-846. [CrossRef]

88. Karimi, M.; Ghazanfari, F.; Fadaei, A.; Ahmadi, L.; Shiran, B.; Rabei, M.; Fallahi, H. The Small-RNA Profiles of Almond (Prunus dulcis Mill.) Reproductive Tissues in Response to Cold Stress. PLoS ONE 2016, 11, e0156519. [CrossRef]

89. Tromp, J. Nutrient reserves in roots of fruit trees, in particular carbohydrates and nitrogen. Plant Soil 1983, 71, 401-413. [CrossRef]

90. Smith, C.L.; Waugh, J.G. Seasonal variations in the carbohydrate and nitrogen content of roots of bearing pecan trees. J. Agric. Res. 1938, 57, 449-460. 
91. Silva, D.D.; Qin, L.; DeBuse, C.; DeJong, T.M. Measuring and modelling seasonal patterns of carbohydrate storage and mobilization in the trunks and root crowns of peach trees. Ann. Bot. 2014, 114, 643-652. [CrossRef] [PubMed]

92. Wood, B.W. Alternate bearing in pecan. In Pecan Husbandry: Challenges and Opportunities; Wood, B.W., Payne, J.A., Eds.; ARS-96; First National Pecan Workshop; US Department of Agriculture, Agricultural Research Services: Springfield, VI, USA, 1991; pp. 180-190.

93. Chen, X.; Qi, S.; Zhang, D.; Li, Y.; An, N.; Zhao, C.; Zhao, J.; Shah, K.; Han, M.; Xing, L. Comparative RNA-sequencing-based transcriptome profiling of buds from profusely flowering 'Qinguan' and weakly flowering 'Nagafu no. 2' apple varieties reveals novel insights into the regulatory mechanisms underlying floral induction. BMC Plant Biol. 2018, 18, 1-21. [CrossRef] [PubMed]

94. Lockwood, D.W.; Sparks, D. Translocation of 14C in 'Stuart' pecan in the spring following assimilation of 14CO2 during the previous growing season. J. Am. Soc. Hort. Sci. 1978, 103, 38-45.

95. Barnett, J.; Mielke, E.A. Alternate bearing: A re-evaluation. Pecan South 1981, 8, 20-30.

96. Wood, W.B.; Conner, P.J.; Worley, R.E. Insight into Alternate Bearing of Pecan. Acta Hortic. 2004, 636, 617-629. [CrossRef]

97. Wahl, V.; Ponnu, J.; Schlereth, A.; Arrivault, S.; Langenecker, T.; Franke, A.; Feil, R.; Lunn, J.E.; Stitt, M.; Schmid, M. Regulation of Flowering by Trehalose-6-Phosphate Signaling in Arabidopsis thaliana. Science 2013, 339, 704-707. [CrossRef]

98. Spann, T.M.; Beede, R.H.; Dejong, T.M. Seasonal carbohydrate storage and mobilization in bearing and non-bearing pistachio (Pistacia vera) trees. Tree Phyiosl. 2008, 28, 207-213. [CrossRef] [PubMed]

99. Zwieniecki, M.; Lampinen, B. Preliminary research development of tree carbohydrate budget based methods for sustainable management of walnut orchards under changing central valley climatic conditions. Calif. Walnut Board Walnut Res. Rep. 2015, 141-157.

100. Oono, Y.; Seki, M.; Satou, M.; Iida, K.; Akiyama, K.; Sakurai, T.; Fujita, M.; Yamaguchi-Shinozaki, K.; Shinozaki, K. Monitoring expression profiles of Arabidopsis genes during cold acclimation and deacclimation using DNA microarrays. Funct. Integr. Genom. 2006, 6, 212-234. [CrossRef]

101. Cook, D.; Fowler, S.; Fiehn, O.; Thomashow, M.F. A prominent role for the CBF cold response pathway in configuring the low temperature metabolome of Arabidopsis. Proc. Natl. Acad. Sci. USA 2004, 101, 15243-15248. [CrossRef]

102. Wang, M.; Xi, D.; Chen, Y.; Zhu, C.; Zhao, Y.; Geng, G. Morphological characterization and transcriptome analysis of pistillate flowering in pecan (Carya illinoinensis). Sci. Hortic. 2019, 257, 1-13. [CrossRef]

103. Tarpley, L.; Sassenrath, G.F. Carbohydrate Profiles during Cotton Floral Bud (Square) Development. J. Agron. Crop Sci. 2006, 192, 363-372. [CrossRef]

104. Simões, F.; Hawerroth, F.J.; Yamamoto, R.R.; Herter, F.G. Water Content and Carbohydrate Dynamics of Pear Trees during Dormancy in Southern Brazil. Acta Hortic. 2014, 1058, 305-312. [CrossRef]

105. Ito, A.; Sakamoto, D.; Moriguchi, T. Carbohydrate metabolism and its possible roles in endodormancy transition in Japanese pear. Sci. Hortic. 2012, 144, 187-194. [CrossRef]

106. Wong, B.L.; Baggett, K.L.; Rye, A.H. Seasonal patterns of reserve and soluble carbohydrates in mature sugar maple (Acer saccharum). Can. J. Bot. 2003, 788, 780-788. [CrossRef]

107. Bonhomme, M.; Peuch, M.; Ameglio, T.; Rageau, R.; Guilliot, A.; Decourteix, M.; Alves, G.; Sakr, S.; Lacointe, A. Carbohydrate uptake from xylem vessels and its distribution among stem tissues and buds in walnut (Juglans regia L.). Tree Physiol. 2009, 30, 89-102. [CrossRef]

108. Borghi, M.; Fernie, A.R. Floral Metabolism of Sugars and Amino Acids: Implications for Pollinators' Preferences and Seed and Fruit Set. Plant Physiol. 2017, 175, 1510-1524. [CrossRef]

109. Jensen, K.H.; Berg-Sorensen, K.; Bruus, H.; Holbrook, N.M.; Liesche, J.; Schulz, A.; Zwieniecki, M.A.; Bohr, T. Sap flow and sugar transport in plants. Rev. Mod. Phys. 2016, 88, 1-63. [CrossRef]

110. Tixier, A.; Sperling, O.; Orozco, J.; Lampinen, B.; Roxas, A.A.; Saa, S.; Earles, J.M.; Zwienieck, M.A. Spring bud growth depends on sugar delivery by xylem and water recirculation by phloem Munch flow in Juglans regia. Planta 2017, 246, 495-508. [CrossRef]

111. Fisher, D.B. Year-round collection of willow sieve-tube exudate. Planta 1983, 159, 529-533. [CrossRef]

112. Yates, I.E.; Sparks, D. Anatomy differs for aborting and nonaborting pistillate flowers in Pecan. J. Am. Soc. Hortic. Sci. 1994, 119, 949-955. [CrossRef] 
113. Sparks, D.; Heath, J.L. Pistillate flower and fruit drop of pecan as a function of time and shoot length. HortScience 1972, 7, 402-404.

114. Sparks, D.; Madden, G.D. Pistillate flower and fruit abortion in pecan as a function of cultivar, time, and pollination. J. Am. Soc. Hortic. Sci. 1985, 110, 219-223.

115. Bennett, J.S. Relationships between Carbohydrate Supply and Reserves and the Reproductive Growth of Grapevines (Vitis vinifera L.). Ph.D. Thesis, Lincoln University, Lincoln, New Zealand, 2002.

116. Rosa, R.D.L.; Rallo, L. Olive floral bud growth and starch content during winter rest and spring bud-break. Hortscience 2000, 35, 1223-1227. [CrossRef]

117. Mansouri Dehshoaibi, R.; Davarinejad, G.; Hokmabadi, H.; Tehranifar, A. Evaluation of proline, proteins and sugar during phonological processes of flower buds of commercial pistachio cultivars. J. Hortic. Sci. 2011, 25, 116-121.

118. Nobari, F.; Afshari, H.; Miri, S.M.; Hokmabadi, H. An Investigation of Cold Tolerance on Chemical Properties (Proline, Protein, and Sugar) of the Flower Buds in Four Commercial Cultivars of Damghan Local Pistachio. J. Nuts 2012, 3, 1-8.

119. Charrier, G.; Poirier, M.; Bonhomme, M.; Lacointe, A.; Améglio, T. Frost hardiness in walnut trees (Juglans regia L.): How to link physiology and modelling? Tree Physiol. 2013, 33, 1229-1241. [CrossRef] [PubMed]

Publisher's Note: MDPI stays neutral with regard to jurisdictional claims in published maps and institutional affiliations. 